DOI: $10.15587 / 2312-8372.2018 .128651$

\title{
Omelyanenko v. ANALYSIS OF CONCEPTUAL ASPECTS OF INSTITUTIONAL AND TECHNOLOGICAL DESIGN
}

Об’єктом дослідження є методологія інституиійно-технологічного проектування. Одним з найбільш проблемних місць є нездатність економічних та соціальних інститутів адаптуватися до змін. Відтак, інституційні трансформації мають враховувати особливості технологічної динаміки та інноваційні пріоритети розвитку, що дозволяє перейти до розробки наукових основ методології інституційно-технологічного проектування.

Для визначення иілей інституційно-технологічного проектування були використані адаптовані методи прийняття рішень на основі оптимізації показників ефективності. Використано також методи, що базуються на основі аналізу схем стратегічного розвитку інновачійних систем та міжгалузевих високотехнологічних комплексів. А також методи пошуку інноваційних шляхів розвитку та методи комплексного економічного аналізу політики розвитку.

Представлено концептуальні основи інституційно-технологічного проектування як механізму створення інституційно-інноваційного середовища, що буде підтримувати життєвий цикл високотехнологічних продуктів та створювати позитивний імідж технологічних можливостей і перспектив крайни. Запропоновано конщептуальну схему інститущійн-технологічного проектування, що грунтується на оцінці поточних технологічних трендів та форсайті, виборі відповідних інституційних інновацій (пакетів інновацій) та розробці інституційних проектів їх впровадження в існуючу інституційну матрицю.

Інституційно-технологічне проектування характеризується орієнтацією на одержання синергетичних ефектів за рахунок технологічних факторів розвитку та структурної перебудови інновачійної системи.

Інтегративним результатом інституційно-технологічного проектування має стати підвищення результативності системи управління за рахунок оптимізацї функціональних обов'язків організаційних структур, застосування інформащійно-комунікаційних технологій та створення ефективної системи моніторингу з метою збалансованого розвитку інноваційної системи.

Ключові слова: інституційно-технологічне проектування, інноваційні мережі, високі технологї, інституиійно-інноваційне середовище.

\section{Introduction}

In the conditions of expanding the range of threats to national security and accelerating scientific and technological progress, the forces and resources of many countries of the world are aimed at innovative processes. This is due to the fact that the security and image of the country, as well as its place in the international political arena, directly depends on the high technology factor. Technologies of this type require large-scale attraction of scientific and logistical resources and embody the frontier of the development of science and technology, the latest discoveries and inventions. However, the success of innovative development differs across countries, which leads to the need to analyze development strategies and policies. Discussion in the scientific plan questions of formation of conditions for innovative breakthroughs and creation of new branches of economy through designing and planning of innovative activity in the country as a whole, in its separate directions and at each enterprise. In these conditions, institutional approaches have obvious advantages, since they allow to form development conditions.

For economic theory and practice of industrial policy management, special importance is attached to ensuring the coordination of key functions of the state and the need to form an innovative economy. One of the most urgent ways to solve this problem is the institutionalization processes, which are a tool for increasing competitiveness on the basis of creating an environment for innovation and realizing the objectives of industrial policy.

\section{The object of research and its technological audit}

The object of research is the methodology of institutional and technological design.

The experience of developed countries shows that it is the orientation towards the development and diffusion of high technologies that guarantee a reliable economic basis of high quality and competitiveness. According to RAND Corporation experts, the use of high technologies will increasingly influence people's health and living standards, and will play a crucial role in ensuring the country's defense capability and protecting the environment.

For the economy, in conditions of accelerating the pace of innovation development, when information and knowledge become important resources, problems arise due to the inability of economic and social institutions to adapt to change. Therefore, institutional transformations must take into account the specifics of technological dynamics 
and innovative development priorities that allows to proceed to the development of the scientific foundations of the methodology of institutional and technological design.

\section{The aim and objectives of research}

The aim of the research is development of the conceptual foundations of institutional and technological design as a methodology for managing innovative development in the context of global innovative transformations, in particular, the transition to new organizational forms of the innovation process. To achieve the aim of research, the following tasks are identified:

1. To conduct a comprehensive analysis of modern trends in managing innovation development.

2. To conduct a system analysis and generalization of modern approaches to the formation of institutional innovations.

3. To develop a scheme for institutional and technological design as a methodology for managing innovation development.

\section{Research of existing solutions of the problem}

The problem of analyzing the institutional factors of global competitiveness and the need to create an institutional and innovative environment on the example of IT companies is considered in the study [1].

The researches [2, 3] address the main issues of the development of innovation systems and the problem of the impact of institutes on economic growth. The research [4] focuses on the factor of institutional innovation as institutional change and social activity. The authors of the study [5] consider institutional innovations in terms of their novelty, utility and legitimacy. The Deloitte series on innovation [6] analytical review states that institutional innovations (new or changed institutions and new relationships between existing institutions) are the result of technological changes and the need for adaptation to them.

Especially useful for understanding the role of institutions and situational management of their configuration is the analytical report of the National Committee of Science and Technology of the USA (2016) [7]. This report provides an opportunity to review the impact of innovation on US national security and identify relevant strategic issues, including taking into account the active interaction between institutions. This aspect becomes particularly promising within the framework of ensuring the security of development resources [8] and developing a strategy for the implementation of national priorities [9], among which the conditions of the institutional environment should also be highlighted.

Numerous studies examine certain aspects of institutional innovation in the context of technological dynamics.

In particular, the study [10] considers the process of institutional design of the environment of innovative enterprises and presents a valuation technique in the example of China. The study [11] examines the stages of Finland's innovation policy as one of the most successful technologybased economies.

The author of the study [12], using the example of the space industry, carries out systematic and technicaleconomic analysis. In the framework of this study, the goals, objectives, results and indicators of activities in the field of space exploration and use were considered in the context of general strategies for the development of hightech sectors of the economy of the country and the world.

The study [13] considers the process of institutionalsynergetic design at the sectoral level. This process comprehensively takes into account the factors of sectoral development, but it should be considered in the broader context of the national innovation system and inter-industry interaction. These factors are the basis for the development of intersectoral high-tech complexes, and then require consideration in the development of strategies.

In the author's previous studies [14, 15], based on the analysis of the role of innovation and technology in ensuring national security, the main areas of application of the ideas of technological institutionalism were identified. In particular, it is proposed their use in the development of national development strategies, taking into account global trends based on the potential for synergy in the «development - security» system. These proposals require further development in terms of their practical implementation.

However, the fundamental principles of purposeful management of institutional dynamics within the framework of development strategies require constant research, as in the current situation the situation in the innovation sphere is constantly changing. This requires identifying pressing problems and determining the prospects for its development in the conditions of technological changes.

\section{Methods of research}

To solve the tasks, the research used both classical scientific methods (analysis and synthesis, logical generalization, analogies, comparative comparison and graphoanalytical methods), and specific methods of the economy of high technologies and innovative management.

In particular, the following methods are used to determine the objectives of institutional and technological design:

- adapted decision-making methods based on optimization of performance indicators;

- methods based on the analysis of schemes for the strategic development of innovation systems and intersectoral high-tech complexes;

- methods of searching for innovative ways of development and methods of integrated economic analysis of development policy.

\section{Research results}

Based on the study [2], which considers the role of institutional factors in ensuring competitiveness, let's suggest to consider the methodology of institutional and technological design. This methodology provides for the creation of such institutional and innovative environment that will support the life cycle of high-tech products and create a positive image of the technological capabilities and prospects of the country.

The modern status of the state is determined by two important integral indicators: the scientific and technological level and the ability to technological development.

In this case, the institutional and technological design is based on such approaches:

- adaptation of the economic system to basic institutional characteristics (level of technological development, principles of the world division of labor); 
- active transformation of the institutional matrix with the aim of preserving the competitiveness (global economic subjectness) of the state on the basis of innovations.

In the context of institutional transformations, let's note that for effective management of resource flows, it is necessary to have clear ideas about modern technologies and the organizational and economic principles of their development. Understanding the specifics of the development of promising technologies is necessary for development of innovation strategies, which should be aimed at organizational and resource support of high-tech industries.

The proposed approach is based on the hypothesis of the need to adapt the institutional mechanism for ensuring national security as an expression of the level of protection of interests with the main trends in the innovation sphere, are as follows:

- the openness of the innovation process, the strengthening of the processes of intersectoral technology transfer and the digitization of business processes leading to the formation of a huge number of organizations and systems that have significant synergistic development potential;

- development of innovative systems, including national and regional ones, deepening and expanding various forms of their integration within the framework of active innovation networks;

- formation of a national innovation system as a complex multi-level and multi-branch structure.

Institutional and technological design is also based on an understanding of current trends, within which international competitive rivalry is increasingly moving into the sphere of control over scarce resources of a qualitatively new nature (the so-called development resources). These resources allow to form and support an institutional and innovative environment that enables the country to promptly form and (or) take leading positions in the growing number of potential high-tech markets with uncertain prospects.

To solve these problems, it is necessary to synthesize the approaches of institutional design to the formation of a fundamental reserve of the innovation system, the satisfaction of business needs in industrial-oriented intellectual property, and the gaining of leadership positions in highly specialized high-tech markets. These tasks need to be addressed in a complex because of the focus on the streams of tasks that the business faces in improving product quality and expanding markets and innovative ideas that can be at the heart of start-ups and the creation of new companies.

These tasks of institutional and technological design are especially important in the current conditions of forming the Industry 4.0, form new organizational conditions for development and significantly accelerate innovation processes. Many developed countries and business giants are active participants in the fourth industrial revolution: state programs, commercial associations and non-profit organizations are created, which aim at eliminating barriers to the creation of the industry. In these conditions, the main is not the classical efficiency, but adaptability the ability to quickly adapt to dynamic qualitatively and quantitatively markets. This forms a new situation of strategic choice, related to redistribution of technology rent and practical planning of innovation-investment processes.
Institutional and technological design is proposed to consider at two levels:

1. Management of technological development within existing sectors and market niches in the fight against competitors.

2. Designing organizational and technological formats for the development of industries and areas of activity, which are currently in their infancy.

These levels take into account national peculiarities and development priorities and allow the system design of technological chains to be implemented with a focus on promising technologies and effects. Thus, the implementation of the objectives of institutional and technological design is implemented by the following managerial and analytical mechanisms:

- identification of areas with the highest priority (current and prospective) and localization of competences (innovation potential, technological excellence, human resources, sectoral opportunities) and their effective use; - creation of a set of organizational advantages (a unique concept or model of development, a special configuration of processes, a unique innovative culture, an ecosystem of innovations, etc.).

Analyzing the technological policy and institutional environment of the high-tech sector of leading countries such as the USA, Japan and the EU, the author of the study [3] notes that «differences in innovation systems reflect differences in economic and political conditions and priorities». According to the researcher, the concept of innovative systems is institutional in nature [4], which confirms the theoretical basis and practical significance of the proposed approach.

A successful example of institutional and technological design can be called the institutional construction of Finland's national innovation system. This country in the 60-70's of XX century began to modify its system of science and technology by creating agencies responsible for planning, implementing and developing initiatives and programs in the R\&D field. At the same time, the main emphasis was on developing resource support for innovative processes.

The main reasons that significantly influenced the formation of an effective innovation system are scientific and technological resources, institutionalization, training and the policy of regionalism. Analysts believe that modernization lasted about 30 years with an evolutionary change in state policy and the creation of mechanisms to stimulate innovative activity in the private sector. At the same time, the authors identify three main stages [6]:

1) the $R \& D$ policy stage (1960-1970s) - the establishment of scientific and technological organizations responsible for planning, financing and coordinating $R \& D$ in the framework of national priorities;

2 ) the stage of technological policy (1980s) - the creation of organizations responsible for the transfer and commercialization of technology;

3 ) the stage of integrated innovation policy (from the 1990s) - assimilation of the provisions of the concept of the national innovation system (ecosystem of innovation) and the principles of the «knowledge society».

This evolution actually reflects the processes in the innovatively successful countries, evolutionarily changing their policies in accordance with national needs and global trends.

For the conceptualization of institutional and technological design, the national innovation system should 
be considered as a system of state, private and public structures (institutions), as well as national institutions and their interaction with the goal of creating, modifying, transferring and using knowledge and technology. The condition for the effectiveness of the consistency of these processes can be called the rule of «four i»:

- institutionalization, which provides for the creation of new institutions (for example, departments, research and educational centers, etc.) or the reorganization of existing structures in order to solve the priority tasks of innovative development, as well as the formation of an appropriate infrastructure;

- integration presupposes the use of an interdisciplinary approach in research and the creation of scientific teams, coordination of efforts to solve problems of a fundamental and applied nature;

- innovation is characterized by the fact that a qualitatively new intellectual product is being manufactured or a technology transfer takes place;

- image that provides for the formation of a positive image of technological opportunities and changes, as well as the country's prospects as a result of transplantation of institutional innovations.

These factors are included in almost all models of innovative development, but should develop systematically (organically) within the framework of national strategies. Therefore, when developing institutional and innovative projects, the synergistic effect can't simply be identified with the economic effect. In addition to quantitative results, it has a qualitative component that shows the contribution of basic innovations to the formation of a new technological order and its impact on the economy through technology transfer and innovative networks.

Fig. 1 shows a conceptual scheme of institutional and technological design, based on such processes:

- evaluation of current technological trends and foresight that should be continuous;

- selection of appropriate institutional innovations (innovation packages);

- development of institutional projects for their implementation in the existing institutional matrix of functional institutes of the innovation system.

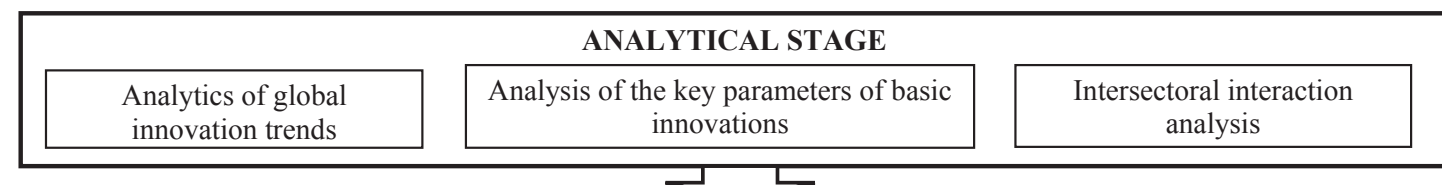

एᄂ

\begin{tabular}{|c|c|}
\hline \multicolumn{2}{|c|}{ ASSESSMENT OF ACTIVE INSTITUTIONAL MATRIX } \\
\begin{tabular}{|c|c|} 
Evaluation of the set of formal and informal links and \\
interregional cooperation and actors of innovation
\end{tabular} & $\begin{array}{c}\text { Assessment of the state effectiveness (level of } \\
\text { quality of institutions, level of transaction costs) }\end{array}$ \\
\hline
\end{tabular}

\section{PL}

DEVELOPMENT OF INSTITUTIONAL PROJECTS

designing a new institution (changing an existing one): a description of the components of the institute and a description of the activities that ensure its creation and interaction with other existing institutions;

identification of economic agents that will be involved in the new interaction scheme;

identification of benefits, benefits or reduction of negative impacts

\begin{tabular}{|c|c|c|c|c|c|c|}
\hline & & & $\sqrt{4}$ & \multicolumn{3}{|l|}{ L } \\
\hline \multicolumn{7}{|c|}{ STRATEGY DEVELOPMENT OF THE STRATEGY OF TRANSPLANTATIONS } \\
\hline \multicolumn{7}{|c|}{ Assessment of the compatibility of institutional transplantation of the existing institutional matrix } \\
\hline \multicolumn{3}{|c|}{$\begin{array}{l}\text { Choose of institutional } \\
\text { transplantation strategy }\end{array}$} & \multicolumn{2}{|c|}{$\begin{array}{l}\text { Establishment of an institutional } \\
\text { transplant infrastructure }\end{array}$} & \multicolumn{2}{|c|}{$\begin{array}{l}\text { Implementation of measures for } \\
\text { adaptation to new institutions }\end{array}$} \\
\hline \multicolumn{4}{|c|}{ 느 } & \multicolumn{3}{|c|}{ ᄅL L } \\
\hline \multicolumn{4}{|c|}{$\begin{array}{l}\text { INSTITUTIONAL-INNOVATIVE PROJECTS } \\
-\quad \text { institutional innovations developed for certain } \\
\text { technological areas (projects) and international } \\
\text { intersectoral high-tech complexes; } \\
-\quad \text { cluster and network synergy of innovative projects; } \\
-\quad \text { building of technological platforms; } \\
-\quad \text { control of structural transitions and synergistic effect }\end{array}$} & \multicolumn{3}{|c|}{$\begin{array}{l}\quad \text { ORGANIZATIONAL AND ECONOMIC } \\
\quad \text { MECHANISM } \\
-\quad \text { program-target development mechanism; } \\
- \text { changes in organizational structures; } \\
-\quad \text { restructuring of the economic system; } \\
- \text { new development tools; } \\
-\quad \text { resource provision and multiplier effects of project } \\
\text { financing; } \\
-\quad \text { synchronization of processes, stages and functions }\end{array}$} \\
\hline & ב & L & & & ב & \\
\hline \multicolumn{7}{|c|}{ GENERATION AND SUPPORT SYSTEM IN THE LIFE CYCLE OF INNOVATIONS } \\
\hline $\begin{array}{l}\text { Subsystem } \\
\text { of } \\
\text { knowledge } \\
\text { generation }\end{array}$ & $\begin{array}{l}\text { Subsystem of } \\
\text { education and } \\
\text { training }\end{array}$ & $\begin{array}{l}\text { Subsystem } \\
\text { of technolo- } \\
\text { gical infrast- } \\
\text { ructure }\end{array}$ & $\begin{array}{c}\text { Subsystem of } \\
\text { financial } \\
\text { infrastructure }\end{array}$ & $\begin{array}{l}\text { Subsystem } \\
\text { of } \\
\text { technology } \\
\text { transfer }\end{array}$ & $\begin{array}{l}\text { Subsystem of } \\
\text { information } \\
\text { infrastructure }\end{array}$ & $\begin{array}{c}\text { Subsystem of } \\
\text { innovation, } \\
\text { production and sales } \\
\text { of products and } \\
\text { services }\end{array}$ \\
\hline
\end{tabular}

Fig. 1. Scheme of institutional and technological design 
Institutional projects as a tool for implementing institutional and technological design are aimed at obtaining synergistic effects and differ from known types of projects by focusing on radical technological breakthroughs or the transition of the economy and innovation system to a new technological platform. A special role in the implementation of institutional projects belongs to supporting the cooperation of key economic actors, allowing to adapt and, if necessary, to make adjustments to existing institutions of the innovation system.

For example, the model of a triple helix illustrates the inclusion in the system of interactions of certain institutions in the stages of creating an innovative product. At the initial stage of innovation generation, authorities and universities interact, then in the process of technology transfer, universities cooperate with business and the results on the market are derived jointly by power and business. The developed model International Q-Helix [15] as a logical continuation of the triple helix and Quadruple Helix models takes into account the whole spectrum of institutions and the international factor of innovative development. Let's also note that the model of technology support network model, which takes into account the system of socio-economic and technological links that allow the functioning of a certain high technology and can be the basis of the methodology of institutional and technological design.

At one time OECD experts formulated the thesis about the role of the state as follows: the introduction of innovations in high-tech industries is expensive and risky, and only in exceptional cases it can be carried out by a separate firm. Risk should be a common thing, and its financing should be directed either by the state itself, or self-organized with the help of venture companies, alliances or business combinations. The lack of knowledge and understanding of the situation in individual firms makes the market unable to finance some highly needed projects. In such cases, state support is required - either indirectly through incentive fiscal policy, or direct selective funding.

An important institutional factor is also culture, in particular an innovative culture, an innovative communication culture and an intellectual property culture. It is necessary, as a minimum, to study and understand, and potentially and rationally develop the cultural values of countries that are global innovation leaders with a correction for national characteristics.

It is also worthwhile to understand the whole essence of institutions and their impact on innovation. For example, it is necessary to develop not only the institutions responsible for the generation of innovations and their transfer, but also institutions with monitoring functions. In this context, let's note that, for example, attracting foreign technologies can lead to the degradation of the national innovation system and often becomes a factor of environmental problems because of the policy of «ecological colonialism» of developed countries.

It should take into account the characteristics of high technology, characterized by both high financial and environmental risks. This problem is of an interdisciplinary nature, requiring the interaction of both innovators and humanitarian specialists.

Therefore, institutional and technological design is characterized by an orientation toward obtaining syner- gistic effects due to technological factors of development and structural adjustment of the innovation system. The integral result of institutional and technological design should be the increase in the effectiveness of the management system by optimizing the functional responsibilities of organizational structures, the use of information and communication technologies and the creation of an effective monitoring system with a view to balanced development of the innovation system.

Thus, the proposed scheme of institutional and technological design is based on strategic planning and management, network development of innovation potential, development and improvement of market mechanisms of financial and economic activity.

\section{SWOT analysis of research results}

Strengths. The strength of research is that the existing Ukrainian analogues on the problems of innovative development are characterized by fragmentation, and the development of foreign authors does not take into account the specifics of the institutional matrix of Ukraine. The methodology of innovation-technological design makes it possible to implement situational analysis within the framework of the evolutionary approach to managing complex systems.

Weaknesses. The weak side is that the practical implementation of the methodology of innovation and technological design requires systemic efforts and strategic thinking and planning, it is difficult to implement in conditions of domination of approaches and strategies based on obtaining short-term benefits.

Opportunities. Opportunities for further research are borrowing the experience of foreign countries to improve the institutional environment and to analyze the possibility of their organic implementation in the framework of national innovation development strategies.

Threats. Threats to the results of conducted research and their practical implementation is that the forms of innovation are constantly changing and vary in different technological sectors that need to be monitored continuously and, in accordance with them, change the orientation of institutional and technological design. It is also possible a time gap between the coordination of institutional innovations in the regulatory and legal field and the actual formation of relevant effective economic institutions on the one hand, and between the formation of institutions and technological trends on the other. In the course of institutional transformations related to innovation and technological processes, uncertainty and risk arise because of the lack of investment guarantees and evolutionary approaches to changing priorities that characterize economic instruments and mechanisms at the national level.

\section{Conclusions}

1. The complex analysis of trends in management of innovative development showed that the formation of innovative policies and system strategies for innovative development is the task of institutional and technological design. This task is able to ensure the effectiveness of strategic planning processes and mechanisms of selforganization, taking into account the specifics of specific high-tech sectors (intersectoral high-tech complexes). 
2. The system analysis and generalization of modern approaches to the development of innovative systems make it possible to identify the role and evolution of institutional innovations that should be a response to various changes and ensure efficient use and organizational and resource support of high-tech industries.

3 . In the course of the research, a scheme of institutional and technological design was developed aimed at developing and implementing institutional projects with the aim of adapting the country to technological trends. The proposed conceptual foundations of institutional and technological design are aimed at developing optimal technological solutions and determining the necessary institutional conditions for technological development on the principles of accumulating intellectual resources and conditions for technological leadership. Also, the fundamentals of institutional and technological design are focused on the formation of drivers of the country's systemic economic development.

\section{Acknowledgements}

The research was publicly funded by Ministry of Education and Science of Ukraine for developing of research project No. 0117U003855 «Institutional and technological design of innovation networks for Ukraine national security systemic providing».

\section{References}

1. Tolkachev S. Innovatsionnaya konkurentsiya: rol' institutsional'noy sredy // Kapital strany. October 7, 2011. URL: http://kapitalrus.ru/articles/article/innovacionnaya konkurenciya_rol institucionalnoj_sredy/

2. National Innovation Systems a Comparative Analysis / ed. by Nelson R. R. New York-Oxford: Oxford University Press, 1993. $541 \mathrm{p}$.

3. Nelson R. R. Bringing institutions into evolutionary growth theory // Journal of Evolutionary Economics. 2002. Vol. 12, No. 1-2. P. 17-28. doi:10.1007/s00191-002-0108-x

4. Hargrave T. J., Van De A. H. A collective action model of institutional innovation // Academy of Management Review. 2006. Vol. 31, No. 4. P. 864-888. doi:10.5465/amr.2006.22527458

5. Raffaely R., Glynn M. A. Institutional Innovation. Novel, Useful and Legitimate // The Oxford Handbook of Creativity,
Innovation, and Entrepreneurship / ed. by Shalley C. E., Hitt M. A., Zhou J. Oxford: Oxford University Press, 2015. P. 407-420. doi:10.1093/oxfordhb/9780199927678.013.0019

6. Hagel J., Seely Brown J. Institutional innovation // Deloitte series on innovation. March 12, 2013. URL: https://www2.deloitte.com/ insights/us/en/topics/innovation/institutional-innovation.html

7. A 21st Century Science, Technology, and Innovation Strategy for America's National Security / Committee on Homeland and National Security of the National Science and Technology Council. Washington, D.C.: Executive Office of the President National Science and Technology Council, May 2016. 13 p. URL: http://www.defenseinnovationmarketplace.mil/resources/ National Security ST Strategy 2016 FINAL.PDF

8. Omelyanenko V. A., Küdrina O. Y., Volodin D. V. Conceptual principles of development resources security analysis // Marketing and Management of Innovations. 2017. No. 2. P. 280-287. doi:10.21272/mmi.2017.2-26

9. Omelyanenko V. Innovation priorities optimization in the context of national technological security ensuring // Marketing and Management of Innovations. 2016. No. 4. P. 226-234.

10. Zhou J., Tang C., Lu T. Institutional Design and Operation for Building up the Innovative Enterprises in China // Proceedings of PICMET 2013: Technology management in the IT-driven services. 2013. URL: http://ieeexplore.ieee.org/document/6641751/

11. Rubvalter D. A., Rudenskiy O. V. Finland: science, technology, and innovation // Informatsionno-analiticheskiy byulleten' TSISN. 2007. Vol. 4. P. 3-53.

12. Payson D. B. Institucionalnoe proektirovanie $\mathrm{v}$ raketno-kosmicheskoi promyshlennosti // Ekonomicheskaia nauka sovremennoy Rossii. 2010. No. 2 (49). P. 64-72.

13. Zagitov I. L. Innovacionno-sinergeticheskoe proektirovanie proizvodstvennyh sistem v mashinostroenii // Ekonomicheskaia sinergetika. 2015. No. 4. URL: http://synergy.esrae.ru/197-922

14. Omelyanenko V. Development of national security strategy components based on the technological institutionalism ideas $/$ Organic combination of social partnership and individual identity as the main factor in ensuring the self-preservation and development of the society: Peer-reviewed materials digest. London: IASHE, 2017. P. 86-89.

15. Krapyvny I., Omelyanenko V., Vernydub N. International innovation networks as new stage of innovation development // Economic Processes Management. 2015. No. 1. URL: http:// epm.fem.sumdu.edu.ua/download/2015_1/2015_1_17.pdf

Omelyanenko Vitaliy, PhD, Department of Business Economics and Administration, Sumy State Pedagogical University named after A. S. Makarenko, Ukraine, e-mail: omvitaliy@gmail.com, ORCID: http://orcid.org/0000-0003-0713-1444 